\title{
Pengaruh Intangible, Assets, Firm Size, Investment Opportunity Set, Probitabilitas dan Coorporate Governance terhadap Firm Value pada Perusahaan Manufaktur Sektor Industri Konsumsi Periode 2014-2016
}

\author{
M Rizky Fauzy \\ Universitas Prima Indonesia \\ rizky.fauzi540@gmail.com
}

\section{Jean Novita}

Universitas Prima Indonesia

jeannovita97@yahoo.co.id

\section{Catherine}

Universitas Prima Indonesia

0205catherine@gmail.com

\section{Monica}

Universitas Prima Indonesia monicayin062@gmail.com

\section{Teresa Derista Maulina Girsang}

Universitas Prima Indonesia

teresiabgt12@gmail.com

Hantono, S.E.,S.Pd.,M.Si.,Ak.,CAP.

Universitas Prima Indonesia

hantono_78@yahoo.com

Ike Rukmana Sari, S.E.,M.M.,

Universitas Prima Indonesia

ikerukmana@yahoo.com

\begin{abstract}
The firm value shows that the prosperity of stakeholders will increase, if the stock price is increased as well. The value of the company becomes very important because it reflects the company's performance which can affect investors' perceptions of the company. This research is meant to find out the influence of intangible asset, firm size, invesment opportunity set, profitability and corporate governance. The research population is consumption industry companies listed on the Indonesia Stock Exchange (IDX) for the 2014-2016 periods. The sample in this study is manufacturing company according to the criteria established and there are 21 manufacturing companies and they have been selected by using purposive sampling. The statistic test instrument uses SPSS 23 version which is carried out to perform classic assumption test, multiple linear regressions analysis, and the hypothesis test. based on the result of normality test, multicolinearity test, heterocedasticity, and
\end{abstract}


autocorrelation, some variables that deviate from the classic asssumption have not been found. the result of the hypothesis test shows that : (1) intangible asset is proven to affect the firm value; (2) Firm size is not proven to affect the firm value ; (3) invesment opportunity set is not proven to affect the firm value ; (4) profitability is not proven to affect the firm value; (5) corporate governance is not proven to affect the firm value.

Keywords Intangible Asset, Firm Size, Investment Opportunity Set, Profitability dan Corporate Governance

\section{PENDAHULUAN}

Perekonomian seluruh dunia saat ini tidaklah memberikan imbas secara langsung pada perekonomian Indonesia. Kondisi politik dalam negeri turut mempengaruhi perekonomian. Saat ini Perekonomian Indonesia telah menciptakan persaingan yang ketat antar perusahaan dalam negeri.Adanya persaingan membuat tiap perusahaan meningkatkan kinerjanya supaya tujuannya bisa tercapai. Tujuan perusahaan yang paling utama adalah menghasilkan laba yang dapat meningkatkan nilai perusahaan serta dapat menguntungkan pemilik perusahaan maupun pemegang saham.

Salah satu cara yang bisa dipilih investor dalam menghimpun dananya selain melalui perusahaan perbankan adalah pasar modal.Investordapat melihat informasi dari fenomena terjadinyafluktuasinya harga saham di pasar modaluntuk menjadi bahan pertimbangan bagi investor untuk berinvestasi pada suatu perusahaan.

Meningkatkan nilai perusahaan dengan memahami faktor-faktor yang mempengaruhinya merupakan tujuan utama dari sebuah perusahaan yang go public, salah satunya perusahaan manufaktur sektor barang konsumsi. Perusahaan manufaktur sektor barang konsumsi sempat mengalami fluktuasi harga saham periode 201-2016, naik turunnya harga saham akan berdampak pada pandangan investor. Tidak konsistennya harga saham membuktikanbahwa nilai dari perusahaan tersebut tidak konsisten, tidak konsistennya harga saham akan membuat pandangan buruk bagi investor. Fluktuasinya nilai perusahaan membuat ketidakpastian keuntungan yang didapat oleh pemegang saham pada perusahaan manufaktur industri barang konsumsi yang ada di bursa efek Indonesia.

Aktiva tidak berwujud memiliki peranan yang sangat penting dan memiliki dampak tersendiri terhadap perusahaan. Contoh dari peran atau manfaat nilai aktiva tidak berwujud bagi perusahaan adalah mengembangkan suatu teknologi baru yang dapat membuat operasi perusahaan menjadi lebih efektif dan efisien.Oleh sebab itu nilai aktiva tidak berwujud harus mendapatkan perhatian yang lebih serius dibandingkan nilai aktiva berwujud baik dalam pengolahan, pengukuran, maupun penyajian.

Ukuran perusahaan biasanya merupakan contoh total aset yang dimiliki suatu perusahaan. Semakin besar ukuranperusahaan maka akan semakin mudah suatu perusahaan dalam memperoleh sumber pendanaan, baik dari internal maupun eksternal. Perusahaan yang berskala besarcenderung akan membuat investor tertarik untuk berinfestasi yang akan berimbas terhadap nilai perusahaan. 
Pengeluaran investasi perusahaantergantung dari peluang yang dimiliki perusahaan dalam memilih investasi. Peluang investasi atau kesempatan investasi merupakan suatu gabungan antara aset yang dimiliki dan pilihan investasi dimasa yang akan datang yang dimana untuk mencapai tujuan suatu perusahaan memiliki kaitan dengan set peluang investasi (investment opportunity set).

Investor menginvestasikan dananya pada suatu perusahaan dengan harapan untuk mendapatkan keuntungan. Semakin tinggi laba yang diperoleh suatu perusahaan maka akan semakin besar pula keuntungan yang didapat investor sehingga nilai perusahaan juga semakin baik.

Usaha pengembangan bisnis Perseroan telah menghasilkan dampak positif.Karenanya, Dewan Komisaris senantiasa mendorong Direksi memaksimalkan berbagai sumber daya yang mereka miliki sehingga dapat mempertahankan sekaligus memperkuat posisi AHI sebagai terdepan dalam bidang improvement dan lifestyle di Tanah Air.Bagi kami, yang terpenting dalam pengembangan setiap usaha adalah peningkatan kualitas aspek tata kelola perusahaan.

\section{LANDASAN TEORI}

\section{II.1. Aktiva Tidak Berwujud}

Menurut Nafarian (2007:45), aset tidak berwujud (intangible asset) meliputi aset tetaptak berwujud, aset lancar tak berwuju dan aset lainnya yang tak berwujud. Aset tetap tak berwujud ( intangible fixed asset ) meliputi hak paten, hak cipta, hak guna usaha, goodwill dan lain-lain. Aset lancar tak berwujud (intangible asset) meliputi piutang usaha, sewa bayar di muka, asuransi bayar di muka dan lain-lain. Aset lainnya yang tak berwujud meliputi biaya pendirian perusahaan (beban ditangguhkan ).

\section{Intangible Asset $=($ Harga Saham $x$ Jumlah saham beredar - Total Ekuitas}

\section{II.2. Ukuran Perusahaan}

Menurut Najmudin (2011:316), ukuran perusahaan yaitu perusahaan yang pada umumnya berskala besar lebih mudah memperoleh hutang dibanding dari perusahaan kecil dikarena terkait dengan tingkat kepercayaan kreditur pada perusahaan-perusahaan besar dimana cenderung lebih terdiversifikasi dan lebih tahan terhadap resiko kebangkrutan.

$$
\text { Ukuran perusahaan }=\text { logaritme natural asset }
$$

\section{II.3. Investment Opportunity Set}

Menurut Harmono (2014:9), investasi modal mempunyai aspek utama kebijakan manajemen keuangan karena investasi adalah bentuk alokasi modal yang nyatanya harus menghasilkan manfaat untuk keuntungan yang diperoleh dimasa yang akan datang.

$$
\begin{gathered}
\text { Price } \\
\text { EarningRatio }
\end{gathered}=\frac{\text { MarketPricePerShare }}{\text { EarningPerShare }}
$$

\section{II.4. Profitabilitas}

Menurut Sudana (2011:22), profitabilitas merupakan ratio yang digunakan untuk mengukur kemampuan suatu perusahaan untuk menghasilkan keuntungan dengan 
melakukan sumber -sumber yang dimiliki perusahaan seperti aktiva, modal atau penjualan perusahaan.

$\begin{gathered}\text { Return on Equity }( \\ \text { ROE })\end{gathered}=\frac{\text { Earning After Interest and Tax }}{\text { Equity }}$

\section{II.5 Tata Kelola Perusahaan}

Menurut Sedarmayanti (2012:2), good governance sektor publik diatikan sebagai suatu proses tata cara pemerintahan yang baik, dengan melibatkan stakeholders, terhadap berbagai kegiatan perekonomian, sosial politik dan pemanfaatan beragam sumber daya seperti sumber daya alam, keuangan dan manusia bagi kepentingan rakyat yang dilaksankan dengan menganut asas : keadilan, pemerataan, persamaan, efisiensi, transparansi dan akuntabilitas.

\section{II.6. Nilai Perusahaan}

Menurut Rodoni, Herni (2014:4), nilai perusahaan hanya ditentukan oleh kemampuan menghasilkan keuntungan(laba) dari aset - aset perusahaan atau kebijakan investasinya dan bahwa cara kegunaan laba dipecah antara dividen dan laba ditahan tidak mempengaruhi nilai ini.

$$
P B V=\frac{\text { Harga saham }}{\text { Nilai Buku }}
$$

\section{II.7. Intangible Assets Terhadap Firm Value}

Menurut Warren, James (2015:511), perusahaan dapat memperoleh hak ekslusif untuk menghasilkan, memperolehdan menjual barang dengan satu keunikan atau lebih. Hak seperti itu disebut hak paten. Suatu perusahaan dapat membeli hak paten dari perusahaan lainnya ataudapat memperolehhak paten yang dikembangkan oleh bagian riset dan pengembangannya sehingga meningkatkan nilai perusahaan.

$\mathbf{H}_{1}$.Intangible Assets Mempunyai Pengaruh Terhadap Firm Value

\section{II.8. Ukuran Perusahaan Terhadap Firm Value}

Menurut Danang (2015:127), bagi perusahaan yang go public, akan lebih mudah mengukur nilai yang muncul adalah bagaimana mengukur nilai perusahaan apabila perusahaan tersebut tidak menjual sahamnya di pasar modal atau tidak go public ? nilai perusahaan yang tidak go publicdapat diukur dengan harga jual seandainya perusahaan tersebut akan dijual yang tidak hanya mencerminkan nilai aset perusahaan tetapi meliputi tingkat risiko usaha dalam prospek perusahaan, lingkungan usaha, manajemen dan faktor - faktor lainnya.

H2.Firm Size Mempunyai Pengaruh Terhadap Firm Value

\section{II.9. Investment Opportunity Set Terhadap Firm Value}

Menurut Bambang (2010:8), suatu perusahaan yang dapat memili proyek - proyek investasi yang tepat, yang memenuhi kebutuhan dananya dalam perimbangan yang 
optimal dan yang mempunyai prospek yang baik. Harga pasar dari sahamnya akan meningkat dalam pasar modal, yang berarti makin tinggi nilai perusahaan tersebut. $\mathbf{H}_{3}$ Investment Opportunity Set Mempunyai Pengaruh Terhadap Firm Value

\section{II.10. Profitabilitas Terhadap Firm Value}

Menurut Danang (2013:113), ketertarikan bagi pemilik perusahaan, yaitu pemegang saham dalam suatu perseroan adalah profitabilitas. Pemilik juga tertarik pada pembagian keuntungan yang menjadikan haknya yaitu seberapa banyak yang diinvestasikan kembali dan seberapa banyak yang dibayarkan sebagai deviden kepada mereka.

$\mathbf{H}_{4}$ Profitabilitas Mempunyai Pengaruh Terhadap Firm Value

\section{II.11. Corporate Governance Terhadap Firm Value}

Menurut Komite Nasional Kebijakan Governance (KNKG) (2010:4), pedoman etika bisnis perusahaan merupakan arahan perilaku yang menjadi tujuan bagi organ perusahaan dan semua pegawai dalam menerapkan nilai-nilai perusahaan serta memabantu mereka untuk memecahkan permasalahan etika yang mereka hadapi dalam melaksanakan kegiatan bisnis.

H5 Corporate Governance Mempunyai Pengaruh Terhadap Firm Value

\section{METODOLOGI PENELITIAN}

\section{III.1. Jenis Penelitian}

Jenis penelitian inimenggunakan pendekatan kuantitatif, bertujuan untuk meneliti suatu populasi atau sampel.Sifat penelitian bersifat kausal yaitu untuk mengetahui apakah ada pengaruh variabel bebas. Intangible Assets $\left(\mathrm{X}_{1}\right)$, Firm Size $\left(\mathrm{X}_{2}\right)$, Investment Opportunity Set $\left(\mathrm{X}_{3}\right)$,Profitabilitas $\left(\mathrm{X}_{4}\right)$, Corporate Governance $\left(\mathrm{X}_{5}\right)$ terhadap Firm Value baik secara parsial maupun simultan. Data yang dipakai adalah yang bersifat sekunder berupa financial report pada perusahaan manufaktur industri konsumsi yang berturutturut dalam Bursa Efek Indonesia (BEI) periode 2014-2016.

\section{III.2. Sampel Dan Teknik Pengambilan Sampel}

Populasi penelitian ini adalah perusahaan manufaktur industri konsumsi yang terdaftar di Bursa Efek Indonesia (BEI) tahun 2014-2016 dengan jumlah total 41perusahaan. Purposive sampling merupakan teknik yang digunakan dalam pengambilan sampel. Jumlah sampel yang didapatkan yaitu 21 perusahaan dan dikalikan dengan tahun penelitian maka didapatkan 63 data penelitan. Kriteria untuk pemilihan sampel pemilihan ini adalah:

1. Perusahaan Manufaktur sektor Industri Konsumsi yang terdaftar di Bursa Efek Indonesia tahun 2014 - 2016.

2. Perusahaan Manufaktur sektor Industri Konsumsi yang mempublikasikan laporan keuangan secara berturut-turut selama periode $2014-2016$.

\section{III.3. Metode Analisis}

Metode penelitian yang digunakan adalah analisis kuantitatif, metode dalam penelitian ini yaitu model regresi linier berganda melalui aplikasi(SPSS). 


\section{HASIL DAN PEMBAHASAN}

\section{IV.1. Hasil Penelitian}

Pengujian Asumsi Klasik untuk mengetahui benar atau salah suatu regresi yang dipakai dalam penelitian. Uji persyaratan analisis ini ada 4 yaitu pengujian normalitas, multikolinearitas, autokorelasi, dan heteroskedastisitas.

1. Uji Normalitas

Pengujian iniuntuk mengetahui dalam sebuah regresi nilainya menghasilkan data yang berdistribusi normal. Suatu model layak digunakan jika mempunyai variabel bebas dan terikat yang mendekati normal atau berdistribusi normal dalam pengujian normalitas penelitian ini menggunakan analisis grafik yaitu grafik Histogram dan grafik Normal PPPlot dan analisis statistik yaitu uji statistik non-parametik Kolmogorov Smirnov (K-S).

\section{Gambar I. Grafik Histogram}

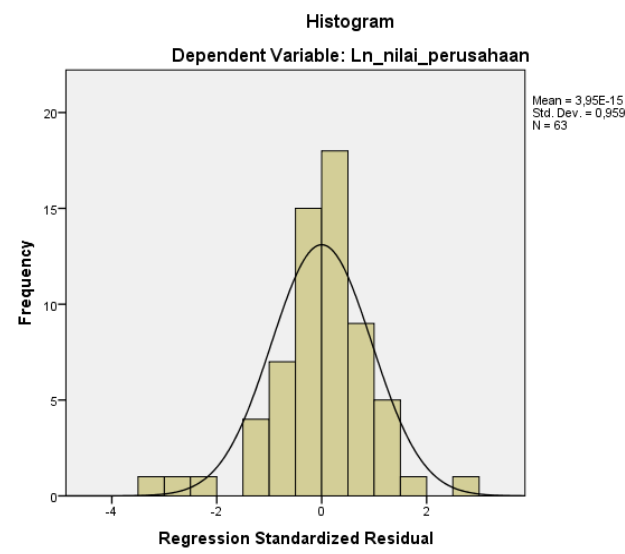

Sumber : Hasil Dari Pengolahan Data SPSS

\section{Gambar 2. Grafik Normal PP-Plot}

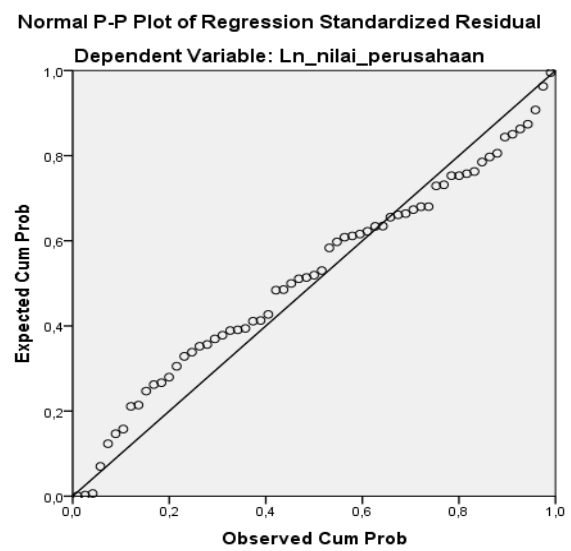

Sumber : Hasil Dari Pengolahan Data SPSS

Dengan melihat grafik histogram maupun grafik normalPP-PloT,disimpulkan bahwa pola dari grafik histogram tersebut tidak melenceng kekiri ataupun kekanan. Sedangkan pada grafik normal PP-Plot terlihat titik-titik menyebar disekitar garis diagonal. Kedua grafik ini menunjukkan bahwa model regresi sesuai dengan asumsi uji normalitas. 
Tabel 1. Kolmogorov Smirnov

\begin{tabular}{|c|c|c|}
\hline & & $\begin{array}{l}\text { Unstandardiz } \\
\text { ed Residual }\end{array}$ \\
\hline$N$ & & 63 \\
\hline \multirow[t]{2}{*}{ Normal Parameters ${ }^{a, b}$} & Mean &, 0000000 \\
\hline & Std. Deviation & ,68090626 \\
\hline \multirow[t]{3}{*}{ Most Extreme Differences } & Absolute & ,099 \\
\hline & Positive &, 073 \\
\hline & Negative &,- 099 \\
\hline Test Statistic & & ,099 \\
\hline Asymp. Sig. (2-tailed) & & $199^{\circ}$ \\
\hline
\end{tabular}

Sumber : Hasil Dari Pengolahan Data SPSS

NilaiAsymp.Sig.(2-tailed) sebesar 0,199 lebih besar dari 0,05. Jadi berdasarkan uji normalitas baik menggunakangrafik maupun statistik menunjukkan bahwa model regresi sesuai dengan asumsi ujinormalitas.

\section{Uji Multikolinieritas}

Pengujian Multikolinearitas ini digunakan untuk meneliti apakah penelitian ditemukan keterkaitan antar-variabel independen. Baik bagi model regresi agar tidak terjadi korelasi antara variabel independen. Untuk mengetahui ada atau tidaknya terjadi multikolinieritas adalah nilai tolerance dan VIF (Value-Inflating Factor), dengan nilai tolerance $\leq 0,10$ dan dengan nilai $\mathrm{VIF} \geq 10$.

Tabel 2. Uji Multikolinieritas

\begin{tabular}{|c|c|c|c|}
\hline \multicolumn{4}{|c|}{ Coefficients $^{a}$} \\
\hline \multirow[b]{2}{*}{ Model } & & \multicolumn{2}{|c|}{ Collinearity Statistics } \\
\hline & & Tolerance & VIF \\
\hline \multirow[t]{5}{*}{1} & $\begin{array}{l}\text { Ln_aktiva_tidak_berwuju } \\
\text { d }\end{array}$ & .500 & 2,000 \\
\hline & Ln_ukuran_perusahaan & ,629 & 1,589 \\
\hline & Ln_IOS &, 646 & 1,549 \\
\hline & Ln_profitabilitas & .574 & 1,743 \\
\hline & Ln_dewan_direksi &, 717 & 1,396 \\
\hline
\end{tabular}

a. Dependent Variable: Ln_nilai_perusahaan

Sumber : Hasil Dari Pengolahan Data SPSS

Berdasarkan hasil uji multikolinieritas pada tabel 2 diketahui bahwa nilai tolerance value semua variabel independen berada di atas 0,10 yaitu sebesar 0,500 untuk Aktiva Tidak Berwujud sebagai $\mathrm{X}_{1}, 0,629$ untuk Ukuran Perusahaan sebagai $\mathrm{X}_{2}, 0,646$ untuk Investment Opportunity Set sebagai $\mathrm{X}_{3}, 0,574$ untuk Profitabilitas sebagai $\mathrm{X}_{4}$ dan 0,717 untuk Tata Kelola Perusahaan sebagai $X_{5}$. Sedangkan nilai VIF antara variabel $X_{1}$ 
Aktiva Tidak Berwujudadalah 2,000, $\mathrm{X}_{2}$ Ukuran Perusahaan adalah 1,589, $\mathrm{X}_{3}$ Investment Opportunity Set adalah 1,549, $\mathrm{X}_{4}$ Profitabilitasadalah 1,743 dan $\mathrm{X}_{5}$ Tata Kelola Perusahaan adalah 1,396 berada di bawah 10. Jadi dapat dikatakan bahwa penelitian ini berdasarkan nilai Tolerance dan VIFnya tidak terjadimultikolinearitas.

3. Uji Autokorelasi

Pengujian Autokorelasi ini dilakukan untuk mengetahui apakah didalam sebuah model regresi linier ada kaitannya dengan kesalahan pengganggu di periode pada tiap variabel independen yang saling berkaitan.

Tabel 3. Uji Autokorelasi

\begin{tabular}{|c|c|c|c|c|c|}
\hline Model & $\mathrm{R}$ & R Square & $\begin{array}{c}\text { Adjusted R } \\
\text { Square }\end{array}$ & $\begin{array}{l}\text { Std. Error of } \\
\text { the Estimate }\end{array}$ & $\begin{array}{l}\text { Durbin- } \\
\text { Watson }\end{array}$ \\
\hline 1 &, $784^{\mathrm{a}}$ &, 615 &, 581 &, 71014 & 1,836 \\
\hline
\end{tabular}

Sumber : Hasil Dari Pengolahan Data SPSS

Pada tabel 3 menunjukkan besarnya nilai durbin-watson sebesar 1,836. Hasil pengujian menurut tabel durbin-watson nilai du $=1,7671$ maka hasil pengujian menunjukkan $1,7671<1,836<2,2329$. Berdasarkan hasil pengujian disimpulkan bahwa model persamaan regresi tidak terjadi autokorelasi baik positif maupun negative karena diatas 1,7671 dan dibawah 2,2329.

\section{Uji Heteroskedastisitas}

Pengujian Heteroskedastisitas dilakukan untuk melihat model regresi, terjadi perbedaan varians residual dari satu bagian dengan bagian lainnya. Jika ditemukan varians residual dari satu bagian dengan pengamatan yang lain tidak berbeda, oleh karena itu dapat dikatakan homoskedastisitas.

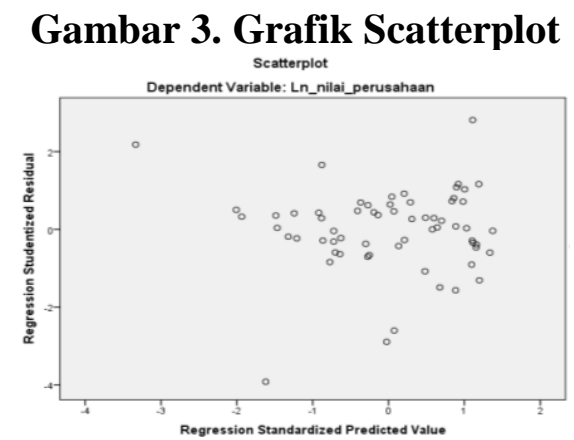

Sumber : Hasil Dari Pengolahan Data SPSS

Berdasarkan gambar 3menunjukkan bahwa titik-titiknya menyebar secara random dan menyebar dari atas sampai ke bawah angka 0 pada sumbu Y. Hal ini dapatdikatakan bahwa datapenelitiantidakmengalami heteroskedastisitas.

\section{IV.2. Analisis Linier Berganda}




\section{Tabel 4.Uji Parsial}

\begin{tabular}{|c|c|c|c|c|c|c|}
\hline \multicolumn{7}{|c|}{ Coefficients $^{a}$} \\
\hline \multirow[b]{2}{*}{ Mode } & & \multicolumn{2}{|c|}{ Unstandardized Coefficients } & \multirow{2}{*}{$\begin{array}{c}\begin{array}{c}\text { Standardized } \\
\text { Coefficients }\end{array} \\
\text { Beta } \\
\end{array}$} & \multirow[b]{2}{*}{$t$} & \multirow[b]{2}{*}{ Sig. } \\
\hline & & $B$ & Std. Error & & & \\
\hline \multirow[t]{6}{*}{1} & (Constant) & 8,344 & 5,393 & & 1,547 & .127 \\
\hline & $\begin{array}{l}\text { Ln_aktiva_tidak_berwuju } \\
\text { d }\end{array}$ & .422 & ,057 & ,864 & 7,438 &, 000 \\
\hline & Ln_ukuran_perusahaan & $-5,257$ & 1,806 &,- 302 & $-2,911$ &, 005 \\
\hline & Ln_IOS & -.026 &, 080 & -.033 &,- 321 & .749 \\
\hline & Ln_profitabilitas & 167 &, 110 &, 166 & 1,526 & .133 \\
\hline & Ln_dewan_direksi &,- 439 &, 304 &,- 140 & $-1,445$ & 154 \\
\hline
\end{tabular}

Sumber : Hasil Dari Pengolahan Data SPSS

$Y=8,344+0,422 X_{1}-5,257 X_{2}-0,026 X_{3}+0,167 X_{4}-0,439 X_{5}$

Berdasarkan tabel 4 dapat dijelaskan hasil pengujian ini adalah.

1. Nilaithitungintangible assets sebesar 7,438>nilait tabel2,00247 dengan signifikannya $0,000<0,05$. Maka dapat disimpulkan bahwa variableX ${ }_{1}$ yaitu intangible assetssecara parsial berpengaruh secara positif signifikan terhadap nilai perusahaan (firm value) pada perusahaan manufaktur sektor Industri konsumsi yang terdaftar di BEI periode 2014-2016.

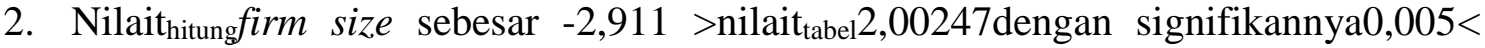
0,05 . Maka dapat disimpulkan bahwavariableX $X_{2}$ yaitu firm size secara parsial berpengaruh secara negatif signifikan terhadap nilai perusahaan (firm value) pada perusahaan manufaktur sektor Industri konsumsi yang terdaftar di BEIperiode 20142016.

3. Nilaithitunginvestment opportunity set sebesar $-0,321<$ nilai $t_{\text {tabel }} 2,00247$ dengan signifikannya $0,749>0,05$. Maka hal ini dapat disimpulkan bahwa variabelX $\mathrm{X}_{3}$ yaitu investment opportunity settidak berpengaruh secara parsial dan tidak adanya signifikan terhadap nilai perusahaan (firm value) pada perusahaan manufaktur sektor Industri konsumsi yang terdaftar di BEI 2014-2016.

4. Nilait ${ }_{h i t u n g}$ profitabilitas sebesar $1,526<$ nilai $t_{\text {tabel }} 2,00247$ dengan signifikannya $0,133>0,05$. Maka dapat disimpulkan bahwa variabelX $X_{4}$ yaitu profitabilitastidak berpengaruh secara parsial dan tidak adanya signifikan terhadap nilai perusahaan (firm value) pada perusahaan manufaktur sektor Industri konsumsi yang terdaftar di BEI periode 2014-2016.

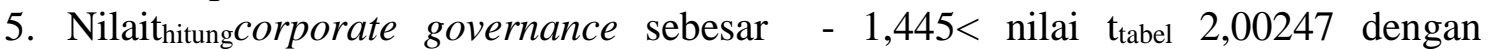
signifikannya 0,154>0,05. Maka dapat disimpulkan bahwa variabel $\mathrm{X}_{5}$ yaitu corporate governance tidak berpengaruh secara parsial dan tidak adanya signifikan terhadap nilai perusahaan (firm value) pada perusahaan manufaktur sektor Industri konsumsi yang terdaftar di BEI periode 2014-2016.

Tabel 5. Uji Simultan 


\begin{tabular}{|c|c|c|c|c|c|c|}
\hline \multicolumn{7}{|c|}{ ANOVA ${ }^{a}$} \\
\hline \multicolumn{2}{|c|}{ Model } & $\begin{array}{l}\text { Sum of } \\
\text { Squares }\end{array}$ & df & Mean Square & $\mathrm{F}$ & Sig. \\
\hline \multirow[t]{3}{*}{1} & Regression & 45,936 & 5 & 9,187 & 18,217 &, $000^{b}$ \\
\hline & Residual & 28,745 & 57 &, 504 & & \\
\hline & Total & 74,681 & 62 & & & \\
\hline
\end{tabular}

Sumber : Hasil Dari Pengolahan Data SPSS

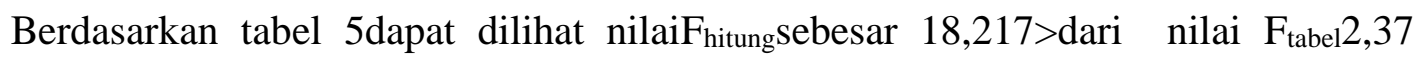
dengan nilai signifikan 0,000<dari 0,05. Maka dapat disimpulkan bahwa intangible asset, firm size, investment opportunity set, profitabilitas dan corporate governance berpengaruh signifikan secara simultan terhadap nilai perusahaan (firm value) pada perusahaan manufaktur sektor industri konsumsi yang terdaftar di BEI periode 20142016.

\section{Tabel 6. Koefisien Determinasi}

Model Summary
\begin{tabular}{|l|c|c|c|c|}
\hline Model & R & R Square & $\begin{array}{c}\text { Adjusted R } \\
\text { Square }\end{array}$ & $\begin{array}{c}\text { Std. Error of } \\
\text { the Estimate }\end{array}$ \\
\hline 1 &, $784^{a}$ &, 615 &, 581 &, 71014 \\
\hline
\end{tabular}
a. Predictors: (Constant), Ln_dewan_direksi, Ln_IOS,
Ln_aktiva_tidak_berwujud, Ln_ukuran_perusahaan,
Ln_profitabilitas
b. Dependent Variable: Ln_nilai_perusahaan

Sumber : Hasil Dari Pengolahan Data SPSS

Berdasarkan tabel 6 uji koefisien determinasi menunjukkan besarnya nilai $\mathrm{R}$ Square $\left(\mathrm{R}^{2}\right)$ atau koefisien determinasi $\left(\mathrm{R}^{2}\right)$ sebesar 0,615 mengindikasi bahwa variasi dari intangible asset, firm size, investment opportunity set, Profitabilitasdancorporate governance hanya menjelaskan nilai perusahaan sebesar $61,5 \%$ dengan sisanya sebesar $38,5 \%$ ini dipengaruhi oleh variabel lainnya yang tidak diteliti.

\section{IV.3. Pembahasan}

Pengaruh intangible asset terhadap nilai perusahaan (firm value). Dari hasil pengujian hipotesis secara statistik diperoleh hasil dengan $t_{\text {hitung }}>t_{\text {tabel }}(7,438>2,00247)$ dengan nilai signifikansi $0,000<0,05$ yang menunjukkan bahwa intangible assetsmemiliki pengaruhsecara positif dan signifikan terhadap nilai perusahaan(firm value) pada perusahaan manufaktur industri konsumsidiBEI periode 2014-2016. Penelitian inisejalan dengan penelitian yang pernah dilakukan oleh Nih Luh Putu Widhiastuti dan Made Yenni Latrini (2015) dengan judul "Pengaruh Return On Asset Dan Aktiva Tidak Berwujud (Intangible Asset) Terhadap Nilai perusahaan (firm value)Dengan Social Responsibility Sebagai Variabel Pemoderasi" yang menyatakan bahwa Intangible Asset memiliki pengaruh secara positifdan signifikan terhadap nilai perusahaan (firm value).

Pengaruh firm size terhadap nilai perusahaan (firm value).Dari hasil pengujian hipotesis secara statistik diperoleh hasil dengan $t_{\text {hitung }}>\mathrm{t}_{\text {tabel }}(-2,911<2,00247)$ dengan nilai signifikansi $0,005<0,05$ yang menunjukkan bahwa ukuran perusahaan memiliki 
pengaruh negatif signifikan terhadap nilai perusahaan pada perusahaan manufaktur industri konsumsidiBEI periode 2014-2016. Penelitian ini berbeda dengan penelitian yang dilakukan oleh I Gusti Ngurah Gede Rudangga dan Gede Merta Sudiarta (2016) dengan judul "Pengaruh Ukuran Perusahaan, Leverage Dan Profitabilitas Terhadap Nilai Perusahaan (firm value)" yang menyatakan bahwa ukuran perusahaan memiliki pengaruhpositif dan signifikan terhadap nilai perusahaan (firm value).

Pengaruh investment opportunity setterhadap nilai perusahaan (firm value). Dari hasil pengujian hipotesis secara statistik diperoleh hasil dengan $\mathrm{t}_{\text {hitung }}<\mathrm{t}_{\text {tabel }}(-0,321<2,00247)$ dengan nilai signifikansi 0,749>0,05 yang menunjukkaninvestment opportunity set tidak memiliki pengaruhterhadap nilai perusahaan(firm value) pada perusahaan manufaktur industri konsumsi di BEI periode 2014-2016. Penelitian ini tidak sama dengan penelitian yang pernah dilakukan oleh Marina Suzuki Hariyanto bersama Putu Vivi Lestari (2015) dengan judul "Pengaruh Struktur Kepemilikan, IOS Dan ROE Terhadap Nilai Perusahaan(firm value) Pada Perusahaan Food And Beverage" yang menyatakan bahwa investment opportunity setmemiliki pengaruh secra positif dan signifikan terhadap nilai perusahaan (firm value).

Pengaruh profitabilitas terhadap nilai perusahaan (firm value).Dari hasil pengujian hipotesis secara statistik diperoleh hasil dengan $t_{\text {hitung }}<t_{\text {tabel }}(1,526<2,00247)$ dengan nilai signifikansi $0,133>0,05$ yang menunjukkan profitabilitas tidakberpengaruh terhadap nilai perusahaan(firm value) pada perusahaan manufaktur industri konsumsi di BEI periode 2014-2016. Penelitian ini berbeda dengan penelitian yang pernah dilakukan oleh Karina MeidiawatidenganTitik Mildawati (2016) dengan judul "Pengaruh Size,Growth, Profitabilitas, Struktur ModalDan Kebijakan DevidenTerhadap Nilai Perusahaan" yang menyatakan bahwa profitabilitasmemiliki pengaruh secarapositif dan signifikan terhadap nilai perusahaan (firm value).

Pengaruh corporate governance terhadap nilai perusahaan (firm value).Dari hasil pengujian hipotesis secara statistik diperoleh hasil dengan $t_{\text {hitung }}<\mathrm{t}$ tabel $(-1,445<$ 2,00247 ) dengan nilai signifikansi $0,154>0,05$ yang menunjukkancorporate governance tidak memiliki pengaruh terhadap nilai perusahaan(firm value)pada perusahaan manufaktur industri konsumsi di BEI periode 2014-2016. Penelitian ini berbeda dengan penelitian yang pernah dilakukan oleh Tutut Suhartanti bersamaNur Fadjrih Asyik (2015) dengan judul "PengaruhCorporate GovernanceTerhadapNilai Perusahaan Dengan Kinerja Keuangan Sebagai Variabel Moderating" yang menyatakan tata kelola perusahaanmemiliki pengaruh secara positif dan signifikan terhadap nilai perusahaan (firm value).

\section{KESIMPULAN}

Kesimpulan dari hasil penelitian ini secara parsial intangible asset berpengaruh secara positif dan signifikan terhadap nilai perusahaan (firm value), firm sizeberpengaruh secara negatif dan signifikan terhadap nilai perusahaan (firm value), investment opportunity set tidak berpengaruh terhadap nilai perusahaan (firm value), profitabilitas tidak berpengaruh terhadap nilai perusahaan (firm value) dancorporate governance tidak berpengaruh terhadap nilai perusahaan (firm value)pengujian simultan intangible assets, firm size, investment opportunity set, profitabilitas dan corporate governancesecara keseluruhan berpengaruh terhadap nilai perusahaan (firm value). 


\section{UCAPAN TERIMA KASIH}

Dalam penyelesaian jurnal ini penulis banyak menerima bantuan dari orang terdekat, baik bantuan secara langsung maupun bantuan tidak langsung. Untuk itu, dengan segenap hati, penulis ingin mengucapkan banyak terima kasih yang sebesar-besarnya kepada semua pihak yang telah membantu terutama untuk Jurnal Ekonomi \& Ekonomi Syariah/Jesya yang telah mengizinkan kami untuk mempublikasikan jurnal kami.

\section{DAFTAR PUSTAKA}

Danang. 2015. Manajemen Keuangan Untuk Perusahaan. Jakarta : CAPS (Center of Academic Publishing Service.

Harmono. 2009. Manajemen Keuangan Berbasis Balanced Scorecard Pendekatan Teori, Kasus dan Riset Bisnis. Cetakan Pertama. Jakarta: Bumi Aksara.

Nafarin, M. 2007. Penganggaran Perusahaan. Ed 4, Jakarta: Salemba Empat.

Najmudin. 2011. Manajemen Keuangan dan Aktualisasi Syar'iyyah Modern. Yogyakarta: C.V Andi Offset.

Sudana, I Made. 2011. Manajemen Keuangan Perumusan Teori \& Praktik. Erlangga.

Rodon. 2014. Manajemen Keuangan Modern. Mitra Wacana Media.

Warren, Carls S. 2015. Pengantar Akuntasi Adaptasi Indonesia. Ed 25, Jakarta:

Salemba Empat.

Widhiastuti, Ni Luh Putu. Latrini, Made Yenni. 2015. Pengaruh Return On Assetdanaktiva tidak berwujud (Intangible Asset)terhadap Nilai Perusahaan (firm value)dengan Corporate Social Responsibilitysebagai variable pemoderasi. Fakultas Ekonomi dan Bisnis Universitas Udayana, Bali, Indonesia. E-Jurnal Akuntansi Universitas Udayana. Tahun 2015, Halaman 370-383 ISSN : 2302-8556

Rudangga, Gede Merta, I Gusti Ngurah Gede. Sudiarta. 2016. Pengaruh Ukuran Perusahaan (firm size), Leveragedan Profitabilitasterhadap Nilai Perusahaan (firm value). Fakultas Ekonomi dan Bisnis Universitas Udayana (UNUD), Bali, Indonesia. E-Jurnal Manajemen Unud Volume 5, Nomor 7. Tahun 2016, Halaman 4394-4422 ISSN : 2302-8912

Hariyanto, Putu Vivi,Marina Suzuki. Lestari. 2015.Pengaruh Struktur Kepemilikan, IOS, dan ROE terhadap Nilai Perusahaan (firm value) pada Perusahaan Foodand Beverage. Fakultas Ekonomi dan Bisnis Universitas Udayana, Bali, Indonesia. E-Jurnal Manajemen Unud Volume 4, Nomor 4. Tahun 2015, Halaman 1599-1626 ISSN : 2302-8912 
Suhartanti, Nur Fadjrih, Tutut. Asyik. 2015.Pengaruh Corporate Governancetehadap Nilai Perusahaan(firm value)dengan Kinerja Keuangansebagai variable moderating.Sekolah Tinggi Ilmu Ekonomi Indonesia (STIESIA) SURABAYA. Jurnal Ilmu \& Riset Akuntansi Volume 4, Nomor 8. Tahun 2015

Meidiawati,Titik, Karina. Mildawati. 2014.Pengaruh Size, Growth, Profitabilitas, Struktur Modal, Kebijakan Devidenterhadap Nilai Perusahaan (firm value). Sekolah Tinggi Ilmu Ekonomi Indonesia (STIESIA) SURABAYA. Jurnal Ilmu \& Riset Akuntansi Volume 5, Nomor 2. Februari 2014, ISSN : 2460-0585 